\title{
8. SITE SURVEYS OF DEEP SEA DRILLING PROJECT SITES 608, 610, AND 611
}

\author{
Colin L. Jacobs, Institute of Oceanographic Sciences, Wormley²
}

\begin{abstract}
This chapter gives localized geological overviews around three of the DSDP Leg 94 drill sites. Difficulties in comparing sites qualitatively are shown to be caused by differences in the site survey data bases.
\end{abstract}

\section{INTRODUCTION}

This chapter gives details of site surveys carried out around Sites 608, 610, and 611 prior to drilling on Leg 94. Each site is dealt with separately in sections describing (1) the regional location and objectives of drilling at the site, (2) the data used in selection of that site, and (3) an interpretation and discussion of the data. The locations of the sites are shown in Figure 1. Two of the sites (608 and 610) had previously been surveyed using the long-range sidescan sonar GLORIA (Somers et al., 1978).

\section{SITE 608}

\section{Regional Location and Objectives}

Site 608 is situated approximately $120 \mathrm{~km}$ south of the WNW-ESE-trending basin and ridge complex known as King's Trough (Searle and Whitmarsh, 1978; Kidd et al., 1982), and approximately $220 \mathrm{~km}$ northwest of the southern part of the Azores-Biscay Rise (Whitmarsh et al., 1982) (Fig. 2). The objectives of drilling at the site were to detect changes in the surface- and bottom-water paleocirculation by analysis of the core samples, and to obtain a reference stratigraphic section for tectonic studies of King's Trough and the Azores-Biscay Rise.

\section{Site Survey}

Selection of the site location was originally based upon early single-channel air-gun profiles obtained by the Institute of Oceanographic Sciences (IOS), U.K., on Discovery Cruises 33 and 54 (Laughton, 1971; Laughton, 1973) (Fig. 3). In 1982 these profiles were augmented by data collected on Farnella Cruise 9 (Revie, 1983). These new data included bathymetry, magnetics, singlechannel air-gun profiles, gravity, and GLORIA data. In early 1983, a high-resolution near-bottom profiler station was run on Discovery Cruise 134 (Francis, personal communication, 1983).

\section{Interpretation and Discussion}

Figures 4 and 5 are maps showing depth to basement and total sediment thickness, compiled from seismic re-

\footnotetext{
${ }^{1}$ Ruddiman, W. F., Kidd, R. B., Thomas, E., et al., Init. Repts. DSDP, 94: Washington (U.S. Govt. Printing Office).

2 Address: Institute of Oceanographic Sciences, Brook Road, Wormley, Godalming, Surrey, GU8 SUB, United Kingdom.
}

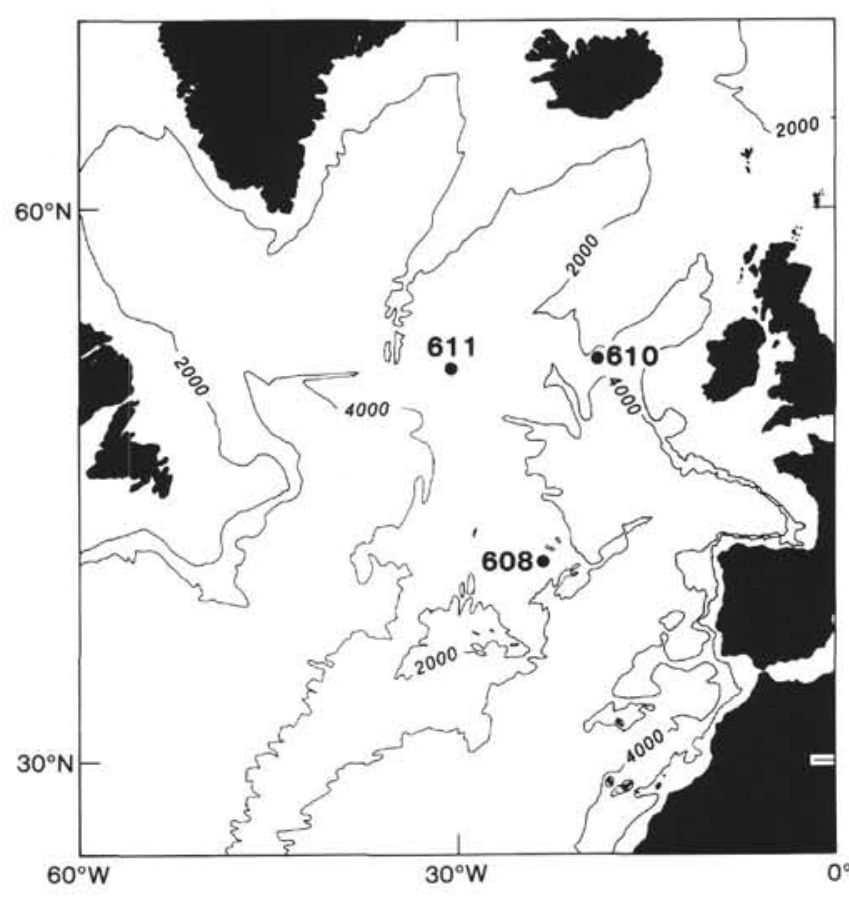

Figure 1. Locations of Sites 608,610 , and 611 , with bathymetry (meters) simplified from General Bathymetric Chart of the Oceans, sheets 5.04 and 5.08 (GEBCO, 1978, 1982).

flection data collected along the tracks shown in Figure 3 . The contours show a general north-south trend, reflecting the structural lineaments of the ocean crust in this part of the North Atlantic (Kidd et al., 1983). The positive features (e.g., at $42^{\circ} 35^{\prime} \mathrm{N}, 23^{\circ} 21^{\prime} \mathrm{W}$ and at $42^{\circ} 55^{\prime} \mathrm{N}, 23^{\circ} 14^{\prime} \mathrm{W}$ ) represent the peaks of faulted basement blocks formed at the Mid-Atlantic Ridge axis. GLORIA data were used to identify fault scarps (e.g., at $43^{\circ} 54^{\prime} \mathrm{N}, 23^{\circ} 15^{\prime} \mathrm{W}$ ) and outcropping basement rocks (e.g., at $42^{\circ} 37^{\prime} \mathrm{N}, 23^{\circ} 02^{\prime} \mathrm{W}$ ) (Fig. 5). GLORIA data were also used to define the shape of the abyssal hills (Fig. 3); the fault trends and basement outcrop were used as a guide to contouring.

One of the more interesting features of Figure 5 is the change in azimuth of the fault trends as mapped from the GLORIA data. The three faults in the north of the area, near $42^{\circ} 53^{\prime} \mathrm{N}, 23^{\circ} 15^{\prime} \mathrm{W}$, have trends of $018^{\circ}$, subparallel to the normal "spreading fabric" $\left(010^{\circ}\right)$ seen on GLORIA records near the Mid-Atlantic Ridge at this latitude (Searle and Laughton, 1977). A second group 


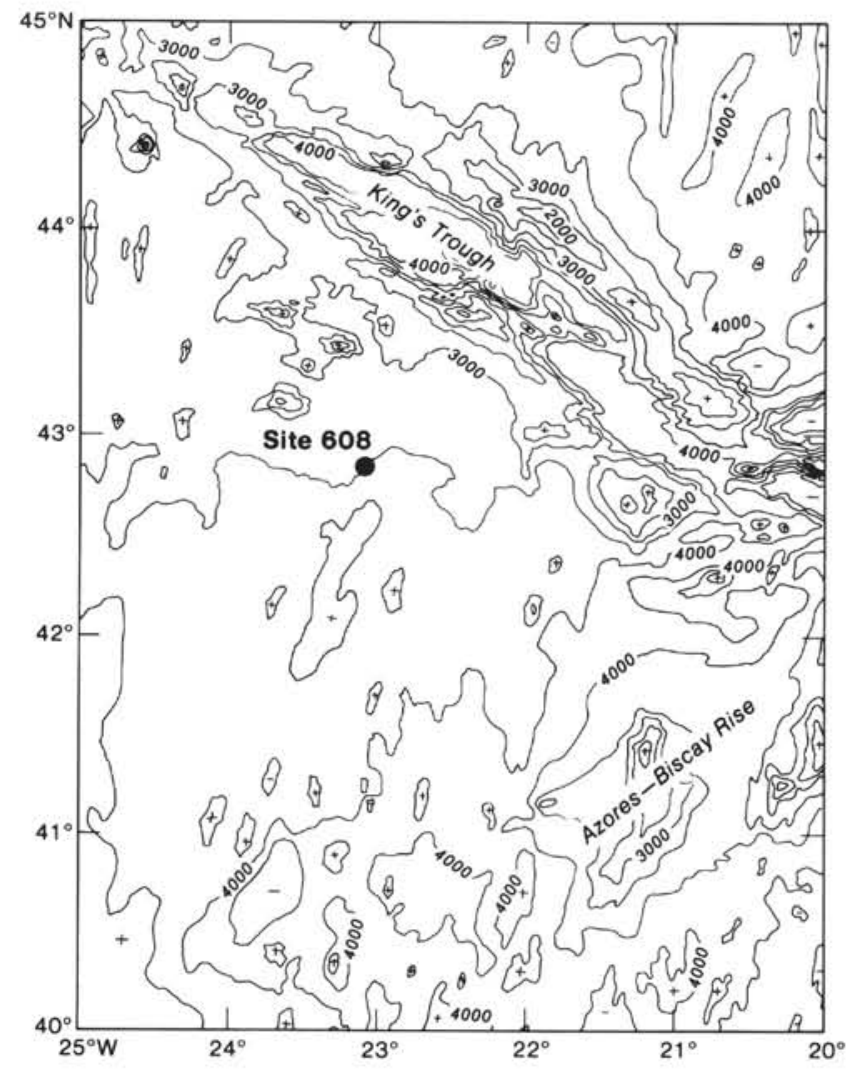

Figure 2. Bathymetry of King's Trough and the Azores-Biscay Rise, from General Bathymetric Chart of the Oceans, sheet 5.08 (GEBCO, 1982). Contour interval $500 \mathrm{~m}$. of faults, concentrated around the outcrop of acoustic basement at $42^{\circ} 36^{\prime} \mathrm{N}, 23^{\circ} 00^{\prime} \mathrm{W}$, shows a trend of $050^{\circ}$, oblique to the normal spreading fabric and almost perpendicular to Fracture Zone "A" of Miles and Kidd (this volume). Searle and Laughton (1977) have suggested that faults with northwesterly trends correlate with regions of dextral offset, and their observation is reflected in Figure 5. In addition, the outcrop of acoustic basement at $42^{\circ} 36^{\prime} \mathrm{N}, 23^{\circ} 00^{\prime} \mathrm{W}$, mentioned earlier, is apparently truncated where it intersects Fracture Zone "A." Site 608 is located on ocean crust that just predates or is of Anomaly 18 age (Miles and Kidd, this volume). Berggren et al. (in press) show this to be approximately 42 $\mathrm{Ma}$. The sediments will therefore reflect the evolution of King's Trough, which began with uplift of an aseismic ridge at about 32 Ma (Kidd et al., 1982).

Figure 6 shows a two-channel seismic reflection profile across Site 608 .

\section{SITE 610}

\section{Regional Location and Objectives}

The site is approximately $6 \mathrm{~km}$ southeast of the axis of the Feni Ridge, a major sediment drift along the western margin of Rockall Trough (Fig. 7). The site location was southwest of that originally planned, to place it in an area covered by GLORIA sonographs (Roberts and Kidd, 1979). The original objectives of drilling at the site were to record isotopic and faunal responses to deepwater overflow from the Norwegian Sea, and to monitor warm currents along the coast of Europe during the late

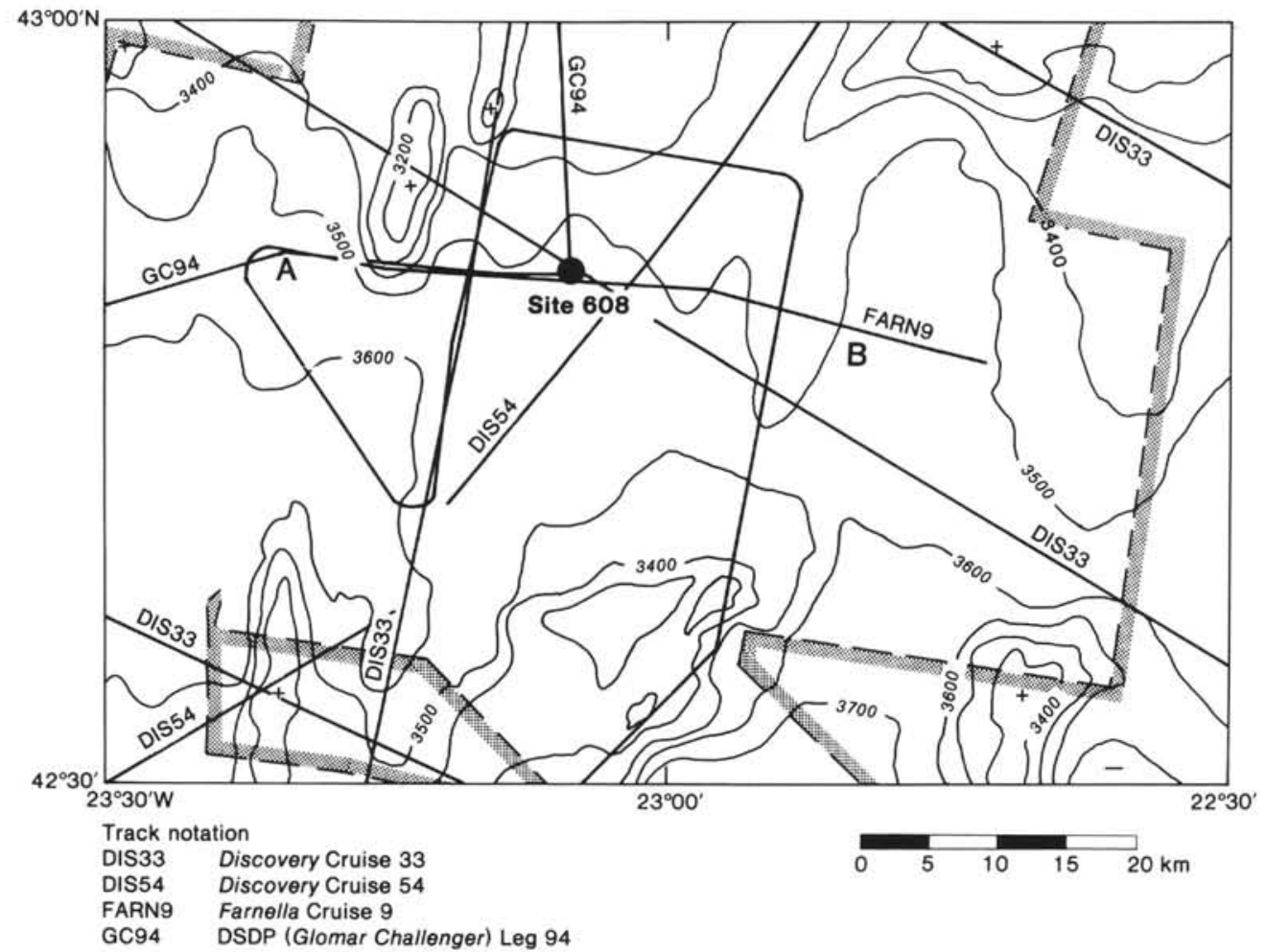

Figure 3. Bathymetry and geophysical data tracks around Site 608. Depths in corrected meters, contour interval $100 \mathrm{~m}$. Dashed line represents limit of GLORIA insonification from Farnella Cruise 9. Stippling indicates area beyond range of GLORIA. A-B indicates location of seismic reflection profile in Figure 6. 


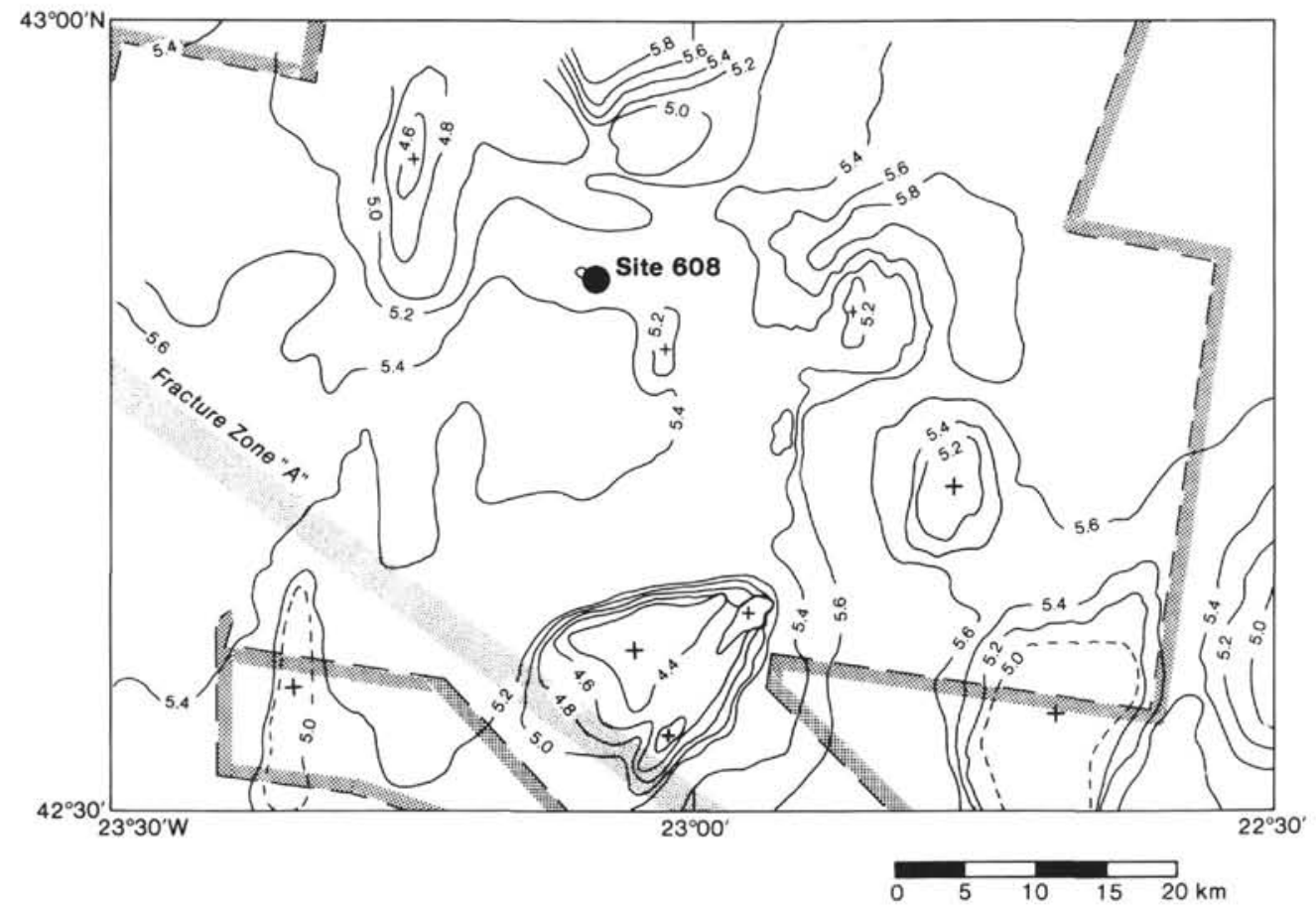

Figure 4. Total depth to basement (in seconds two-way traveltime) in the area around Site 608. Also shown: Fracture Zone "A" of Miles and Kidd (this volume). Contour interval $0.2 \mathrm{~s}$. Dashed line represents limit of GLORIA insonification. Stippling indicates area beyond range of GLORIA.

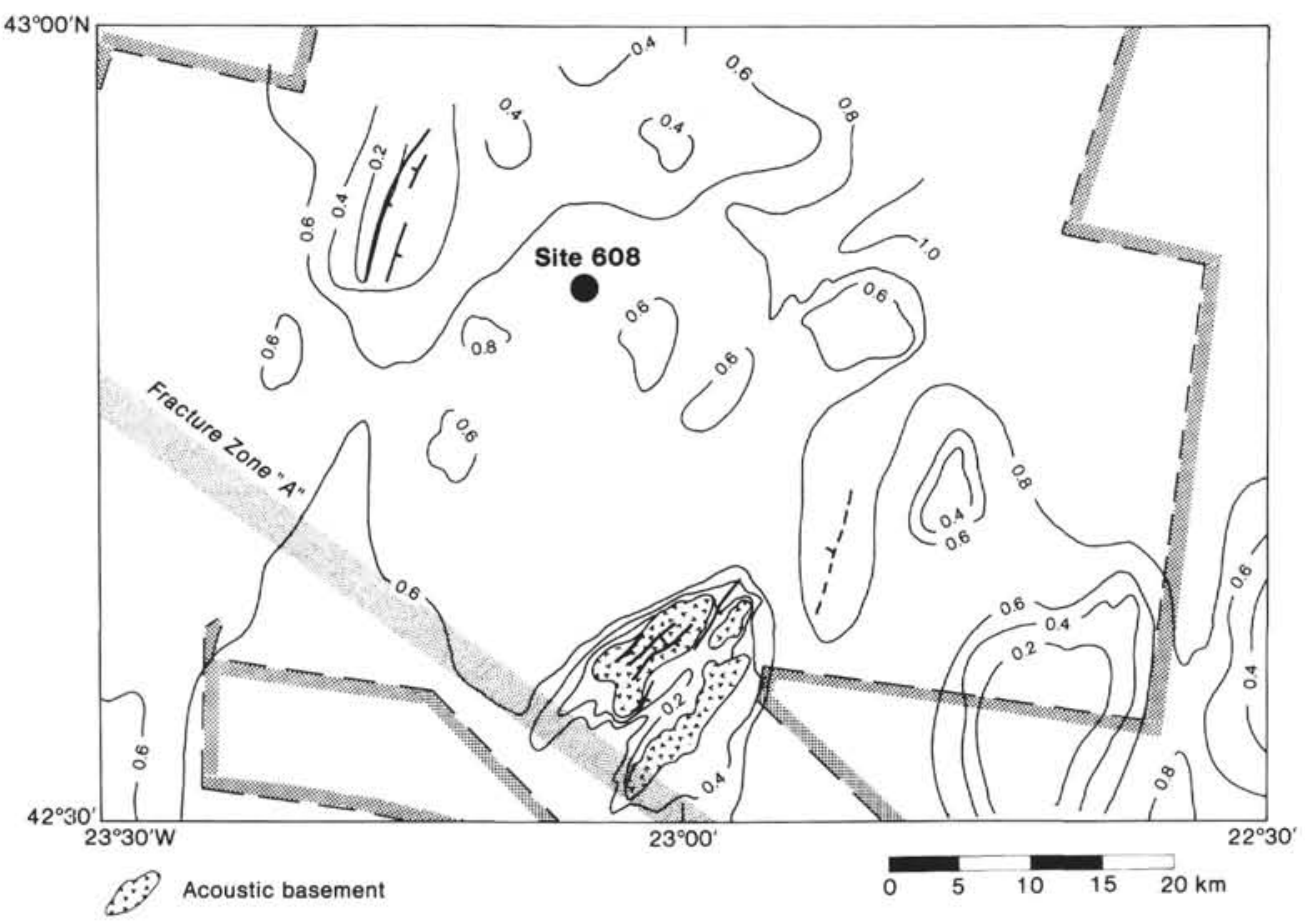

Figure 5. Sediment thickness (in seconds two-way traveltime) in the area around Site 608. Also shown: acoustic basement outcrop and Fracture Zone " $\mathrm{A}$ " of Miles and Kidd (this volume). Contour interval $0.2 \mathrm{~s}$. Faults are taken from GLORIA data. Dashed line represents limit of GLORIA insonification. Stippling indicates area beyond range of GLORIA. 


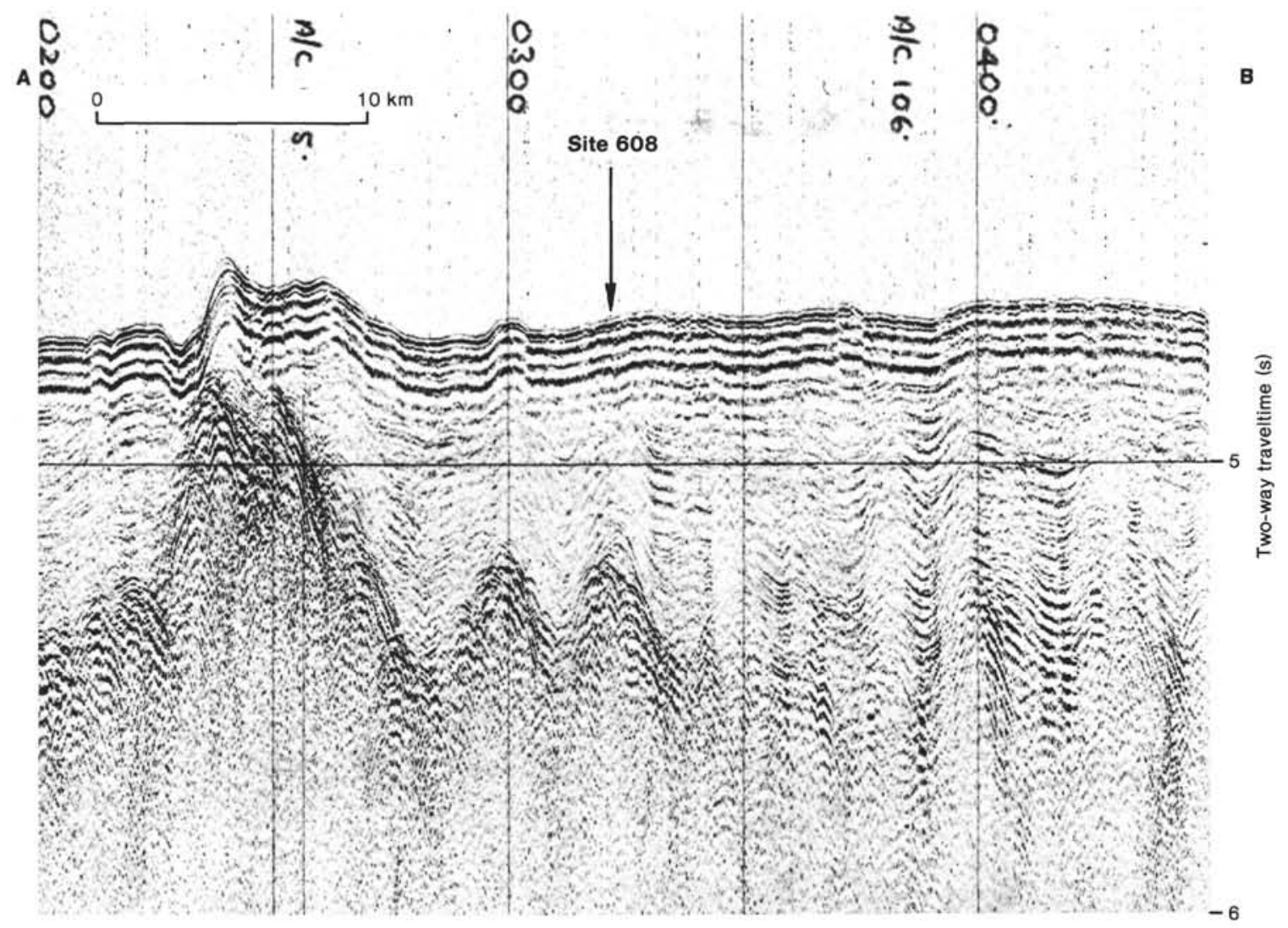

Figure 6. Two-channel seismic reflection profile across Site 608, obtained on Farnella Cruise 9. Location of section shown by line A-B on Figure 3.

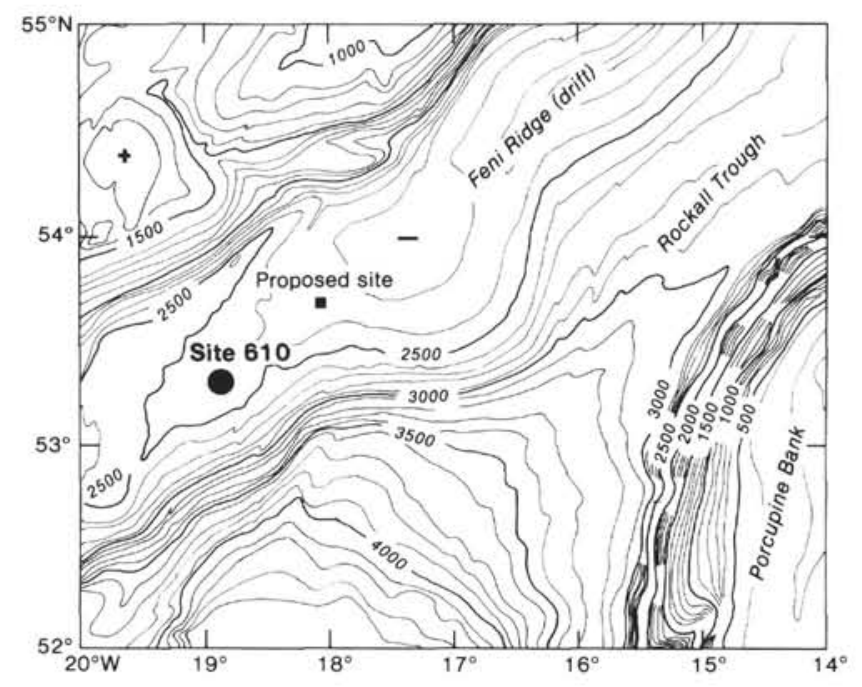

Figure 7. Bathymetry of southern Feni Ridge (drift) and southern Rockall Trough. From Laughton et al. (1982). Contour interval $100 \mathrm{~m}$.

Neogene. Further objectives related to the development of sediment wave fields and the geological history of the Feni Ridge sediment drift were pursued after the change in site location.

\section{Site Survey}

The southern Rockall Trough has been the subject of intensive research activity (e.g., Scrutton and Roberts, 1971; Roberts, 1975; Kristofferson, 1978; Roberts et al., 1981), and a large quantity of seismic reflection data is available. Originally it was planned to locate Site 610 on the multichannel seismic reflection profile WI-32, but the site position was revised at sea, as already stated. The new position selected is near the intersection of single-channel seismic reflection profiles from Discovery Cruise 84 (Laughton, 1977) and DSDP Leg 12 (Laughton, Berggren, et al., 1972). Other useful profiles include a Jean Charcot single-channel seismic reflection profile and the multichannel profile WI-32, located some 65 and $90 \mathrm{~km}$ northeast of the site, respectively. GLORIA coverage over the site was obtained on Discovery Cruise 84. These data and their interpretations have been presented by Roberts and Kidd (1979), and will not be repeated here.

\section{Interpretation and Discussion}

Interpretation of seismic reflection profiles in this area is complicated by the difficulty in correlating reflectors between adjacent profiles obtained using different seismic acquisition systems. Only multichannel lines, such as WI-32, and a limited number of high-quality single- 
channel profiles (e.g., Discovery Cruise 84 and Jean Charcot 04) provide significant penetration and resolution to allow reasonable track-to-track correlation of reflectors. Figure 8 shows three examples of seismic reflection profiles, all obtained using different data acquisition systems. One of the most obvious features is the lack of penetration from the water-gun profiles of DSDP Leg 94 (this probably results from the filter settings of the data acquisition system): only the first major reflector, at $0.6-0.8 \mathrm{~s}$ sub-bottom, was detected. This compares with more than $3.0 \mathrm{~s}$ sub-bottom penetration from the Discovery Cruise 84 profile, which for a time runs subparallel to and less than $500 \mathrm{~m}$ from the Leg 94 profile (Fig. 9). Depth-to-basement and sediment-thickness maps have not been compiled, because there are not enough high-quality data available in the immediate vicinity of the site to allow construction of a meaningful map.

Roberts and Kidd (1979) show that over much of the Feni Ridge the sediment waves display two trends, one parallel and one orthogonal to the regional contours. Kidd and Hill (this volume) show that these trends continue around Site 610. Many of the waves are of limited extent ( $<10 \mathrm{~km}$ long) and have mean wavelengths of approximately $4 \mathrm{~km}$. The Discovery Cruise 84 seismic profile in Figure 8 shows that the waves can be traced to a sub-bottom depth of more than $0.5 \mathrm{~s}$ (two-way traveltime), which equates with a middle Miocene age (Site 610 report, this volume). Figure 10 shows a section of water-gun record from Leg 94 which displays the complex internal structure of the sediment waves down to approximately $415 \mathrm{~m}$ sub-bottom.

This area contains a number of lava flows and sill complexes of early Tertiary age (Roberts, 1975; Roberts et al., 1981). These lavas and sills tend to obscure deeper reflectors, so that the acoustic basement seen on the seismic reflection profiles in this area may not represent "true basement" (or crust). Using the data of Roberts et al. (1981), we located the Discovery Cruise 84 and DSDP Leg 94 profiles over continental crust, with the continent/ocean crustal boundary located at approximately shot point 2480 on the WI-32 multichannel profile. No expression of this is seen in Figure 8, possibly owing to blanketing of any deeper reflectors by the aforementioned lavas and sills.

The large number of seismic reflection profiles in this area will allow widespread extrapolation of dated seismic reflectors away from the drill site, enabling a detailed history of the Feni Ridge sediment drift to be worked out (Masson and Kidd, this volume).

\section{SITE 611}

\section{Regional Location and Objectives}

The site is near the southern end of Gardar Ridge, approximately $90 \mathrm{~km}$ north-northwest of the intersection of Charlie Gibbs Fracture Zone with the Mid-Atlantic Ridge (Fig. 11). The objectives of drilling at the site were to document the paleoenvironmental history related to late Neogene changes in bottom- and surfacewater circulation, linked to overflow of Norwegian Sea water over the Iceland-Faroe ridge. Further objectives were to record changes in deep-water flow through Charlie Gibbs Fracture Zone and to study the overall history of sediment wave formation.

\section{Site Survey}

The site was originally chosen using Vema Cruise 2706 and Discovery Cruise 131 (Whitmarsh, 1982) singlechannel seismic reflection profile data and a $10-\mathrm{m}$ core obtained during Vema Cruise 27-06. Other data available for the area were a single-channel seismic reflection profile from Vema Cruise $30-12$ and $3.5-\mathrm{kHz}$ profiles from Vema Cruises 27-06 and 30-12 and part of Discovery Cruise 131 (Fig. 12). Soundings were available from the Gibbs and Discovery tracks.

\section{Interpretation and Discussion}

Figure 13 shows a single-channel seismic reflection profile from Discovery Cruise 131, across Site 611. The depth-to-basement map (Fig. 14) was constructed using data obtained from the cruises mentioned above, with the addition of the DSDP Leg 94 seismic reflection profiles. The most obvious of the two main structural lineaments is the series of basement highs and lows, trending NNE-SSW; these represent the peaks and troughs of the faulted ocean crust developed at the Mid-Atlantic Ridge axis (Searle, 1981). The second, less obvious, trend runs approximately east-west and manifests itself as an inflection in the contours at $52^{\circ} 49^{\prime} \mathrm{N}, 30^{\circ} 20^{\prime} \mathrm{W}$, and also in the basement low at $52^{\circ} 53^{\prime} \mathrm{N}, 30^{\circ} 11^{\prime} \mathrm{W}$. It can also be seen in the east-west elongation of the basement low at $52^{\circ} 49^{\prime} \mathrm{N}, 30^{\circ} 29^{\prime} \mathrm{W}$. This east-west trend represents the buried part of the northern transform domain of Charlie Gibbs Fracture Zone. The ocean crust beneath Site 611 just predates Anomaly 13 (Vogt and Avery, 1974), with an age of approximately $35 \mathrm{Ma}$ (Berggren et al., in press). Figure 15 is a sediment-thickness map compiled from the data used for Figure 14.

Figure 16 shows a $3.5-\mathrm{kHz}$ profile across Site 611 . This profile indicates little or no sediment wave migration, and has two prominant reflectors at approximately 12 and $30 \mathrm{~m}$ sub-bottom. Figure 17 is a map of sediment wave crests picked principally from $3.5-\mathrm{kHz}$ profiles. The trend of the waves changes from subparallel to the regional contours at $52^{\circ} 52^{\prime} \mathrm{N}, 30^{\circ} 15^{\prime} \mathrm{W}$ to oblique to the contours south of $52^{\circ} 48^{\prime} \mathrm{N}$, reflecting the change in direction of bottom-current flow from northeast-southwest to approximately east-west (Jones et al., 1970). The position of the drill site near the toe of the sediment drift should allow determination of changes in the direction of bottom-water flow through the Charlie Gibbs Fracture Zone, as well as determination of the overall history of sediment drift formation.

It is interesting to compare the sediment waves at Sites 610 and 611 . At Site 610 , the sediment waves are near the axis of the sediment drift, whereas at Site 611 the sediment waves are near the toe of the sediment drift (Site 610,611 reports, this volume). Kidd and Hill (this volume) show that at Site 610 the sediment waves display two trends, individual waves being of rather limited extent (along-axis) and sometimes bifurcating. At Site 


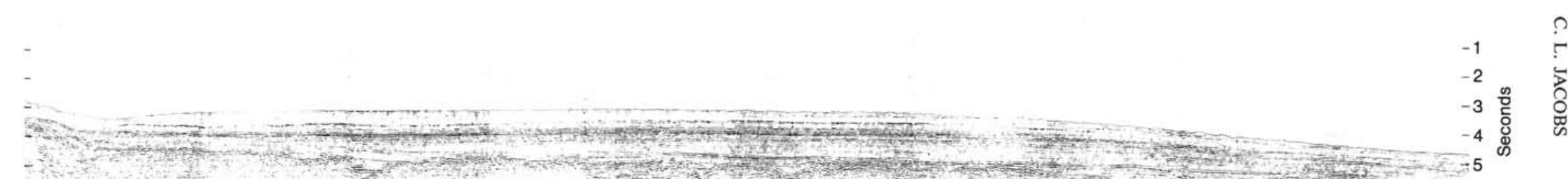

$30 \mathrm{~km}$

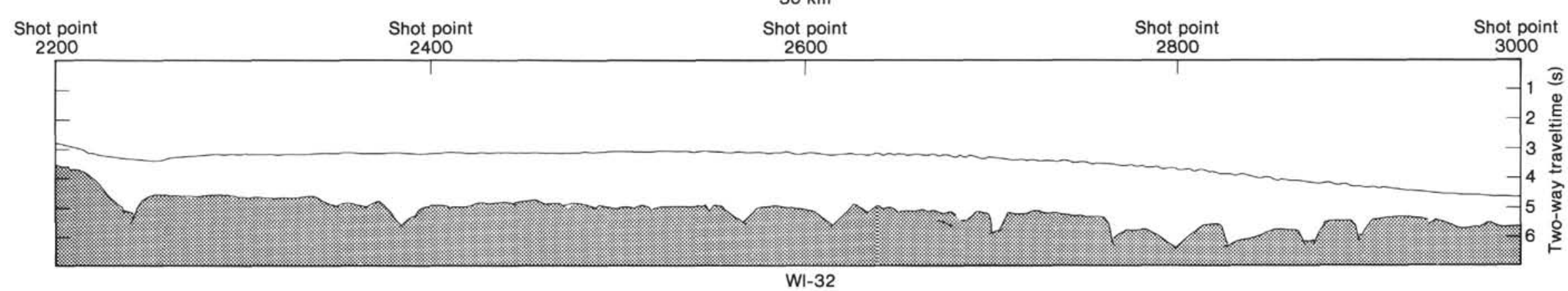

Site 610

(projected)
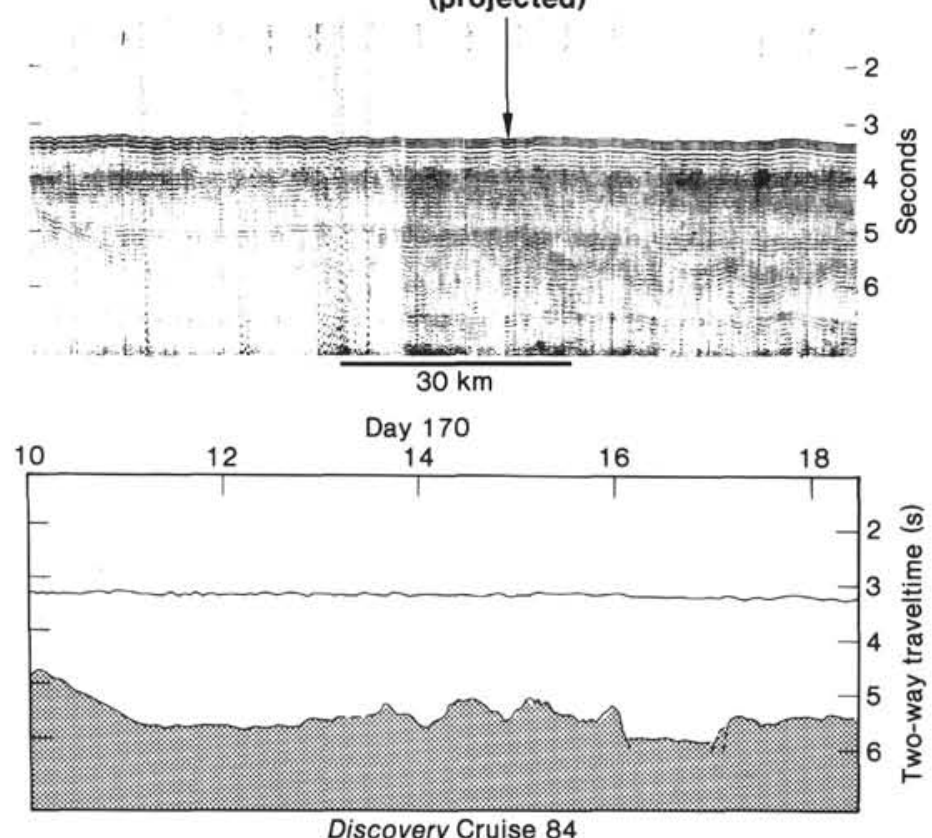

Site 610

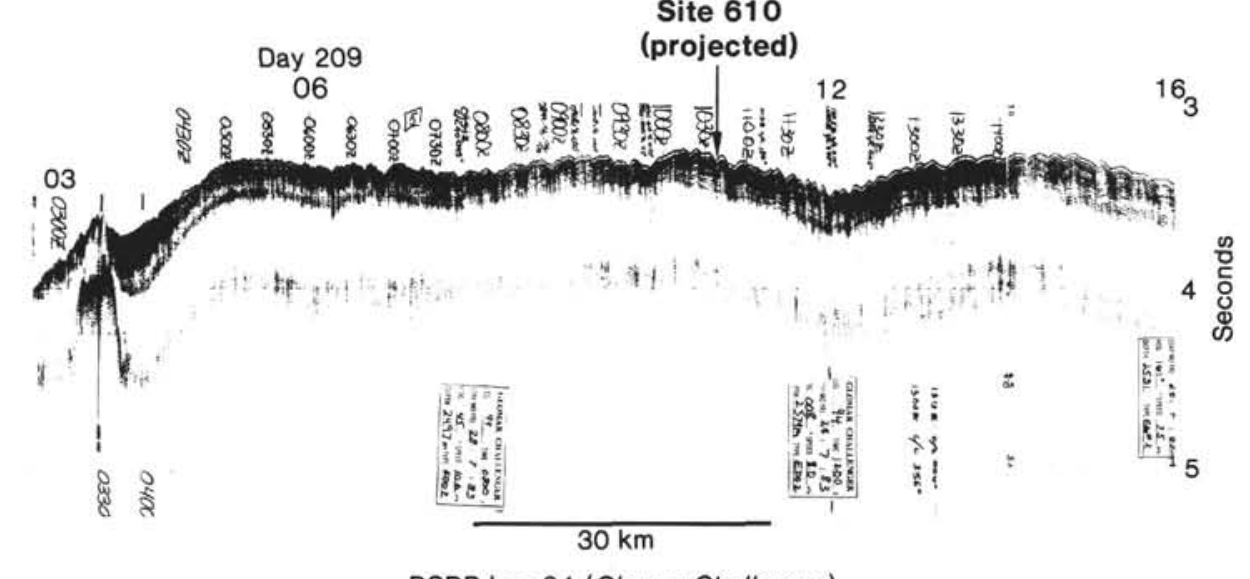

DSDP Leg 94 (Glomar Challenger)

Figure 8. Examples of seismic reflection profiles, with interpretations, from near Site 610. Acoustic basement is stippled. Locations of the profiles are shown in Figure 9. 


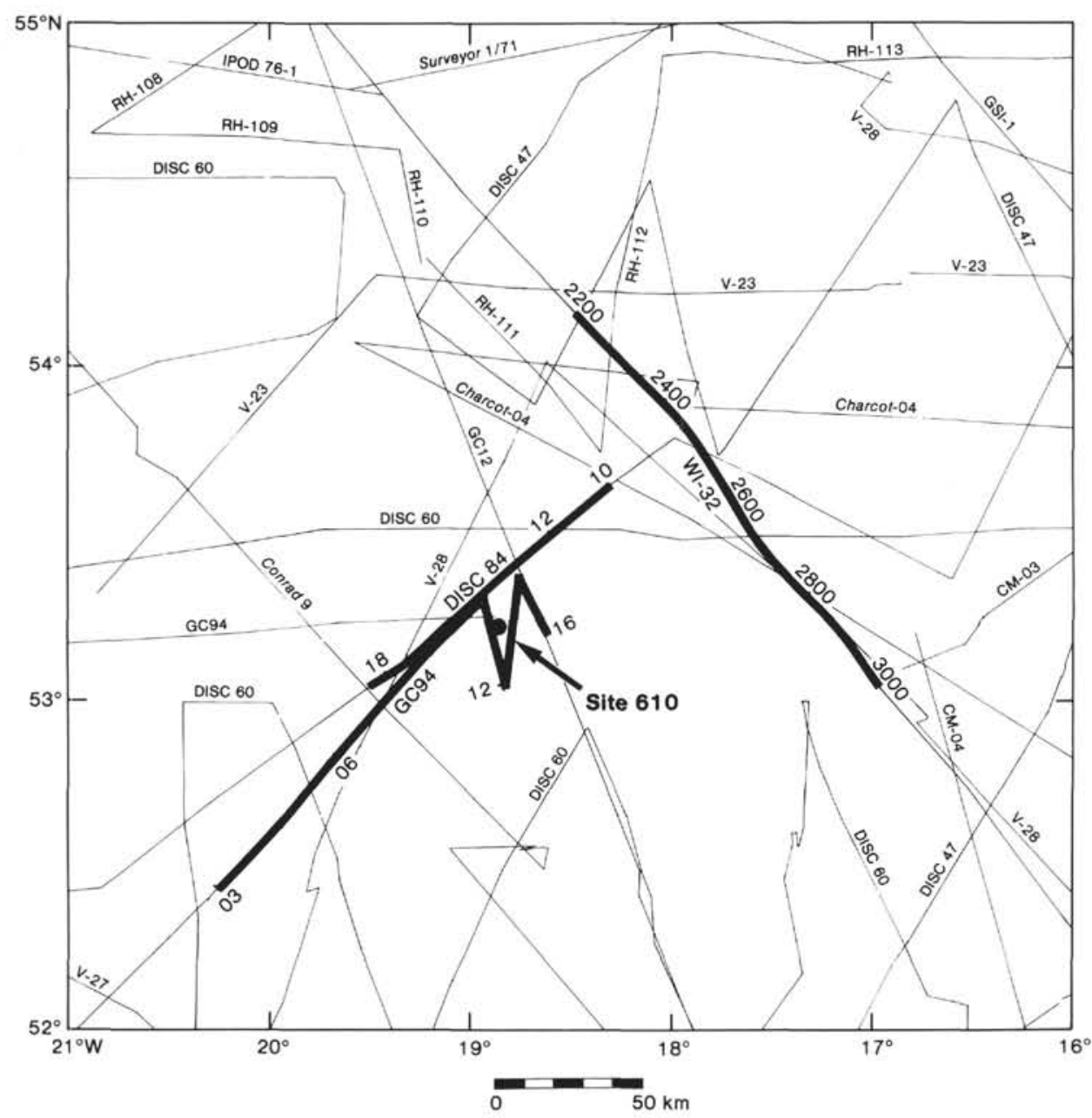

Figure 9. Locations of seismic reflection profiles near Site 610. Heavy lines represent profiles shown in Figure 8.

611 only one trend is seen (although this does change direction downslope), with no direct evidence of bifurcation or interference. If, however, some of the crest trends on Figure 17 were extrapolated away from the tracksfor example, at $52^{\circ} 49^{\prime} \mathrm{N}, 30^{\circ} 22^{\prime} \mathrm{W}$ - then interference and bifurcation would be apparent.

\section{CONCLUSIONS}

This chapter describes how pre- and post-cruise underway geophysical data have been used to produce a geological overview of the site areas. Several inconsistencies are highlighted, the most notable being those arising from the difficulty of comparing sites that have been surveyed using different techniques and survey tools.

The use of GLORIIA at Site 610 has provided a view of the true interrelationship of adjacent sediment waves (Kidd and Hill, this volume); at Site 611, the wave trends can only be inferred by correlation between adjacent profiles. This leads to obvious difficulties when trying to compare qualitatively the sediment wave patterns at the two sites. The poor quality of many single-channel seismic reflection profiles around Site 610 has shown a need for the site survey data acquisition to be planned more carefully.

\section{ACKNOWLEDGMENTS}

I should like to thank Dr. R. B. Kidd for helpful discussions during the preparation of this chapter. I should also like to extend my thanks to all those who took part in the cruises mentioned in this chapter. D. G. Masson and P. R. Miles are thanked for critical reviews of an early draft. I thank two anonymous referees for useful comments and criticism.

\section{REFERENCES}

Berggren, W. A., Kent, D. V., and Van Couvering, J. A., in press. Neogene geochronology and chronostratigraphy. Geol. Soc. London Mem.

GEBCO (General Bathymetric Chart of the Oceans), 1978. Sheet 5.04 IHO and IOC: Ottawa (Canadian Hydrographic Service). 1982. Sheet 5.08 IHO and IOC: Ottawa (Canadian Hydrographic Service).

Jones, E. J. W., Ewing, M., Ewing, J. I., and Eittreim, S. L., 1970. Influences of Norwegian Sea overflow water on sedimentation in the northern North Atlantic and Labrador Sea. J. Geophys. Res., 75:1655-1680.

Kidd, R. B., Searle, R. C., Ramsay, A. T. S., Prichard, H., and Mitchell, J., 1982. The geology and formation of King's Trough, northeast Atlantic Ocean. Mar. Geol., 48:1-30.

Kidd, R. B., Searle, R. C., Weaver, P. P. E., Jacobs, C. L., Huggett, Q. J., et al., 1983. King's Trough flank: Geological and geophysical investigations of its suitability for high-level radioactive waste disposal. Inst. Oceanogr. Sci. Rept., 166.

Kristofferson, Y., 1978. Sea-floor spreading and the early opening of the North Atlantic. Earth Planet. Sci. Lett., 38:273-290. 
Laughton, A. S., 1971. RRS Discovery Cruise 33: April-May 1970. DSDP site surveys and geology and geophysics around King's Trough. Nat. Inst. Oceanogr. Cruise Rept., 33.

1973. RRS Discovery Cruise 54: 29 June-15 August 1973. GLORIA studies of the Mid-Atlantic Ridge (FAMOUS Area) and the Azores-Gibralter Plate boundary. Inst. Oceanogr. Sci. Cruise Rept., 2.

, 1977. RSS Discovery Cruise 84: 15 June-28 July 1977. Geophysical and geological studies of the Charlie-Gibbs Fracture Zone, the Reykjanes Ridge, and King's Trough. Inst. Oceanogr. Sci. Cruise Rept. 60.

Laughton, A. S., Berggren, W. A., et al., 1972. Init. Repts. DSDP, 12: Washington (U.S. Govt. Printing Office).

Laughton, A. S., Roberts, D. G., and Hunter, P. M., 1982. Bathymetry of the northeast Atlantic, Sheet 1: Reykjanes Ridge and Rockall Plateau. Scale 1:2,400,000 at $41^{\circ} \mathrm{N}$. Hydrographic Department (Tannton). C6566

Revie, J. A., 1983. M/V Farnella Cruises 8 and 9/82: 26 February-26 March 1982. Geophysical studies in the Nares Abyssal Plain and the King's Trough flank. Recovery of tide gauges deployed in 1981. Inst. Oceanogr. Sci. Cruise Rept., 145.

Roberts, D. G., 1975. Marine geology of the Rockall Plateau and Trough. Phil. Trans. R. Soc. London, Ser. A, 278:447-509.

Roberts, D. G., and Kidd, R. B., 1979. Abyssal sediment wave fields on Feni Ridge, Rockall Trough: Long-range sonar studies. Mar. Geol., 33:175-191.

3.0

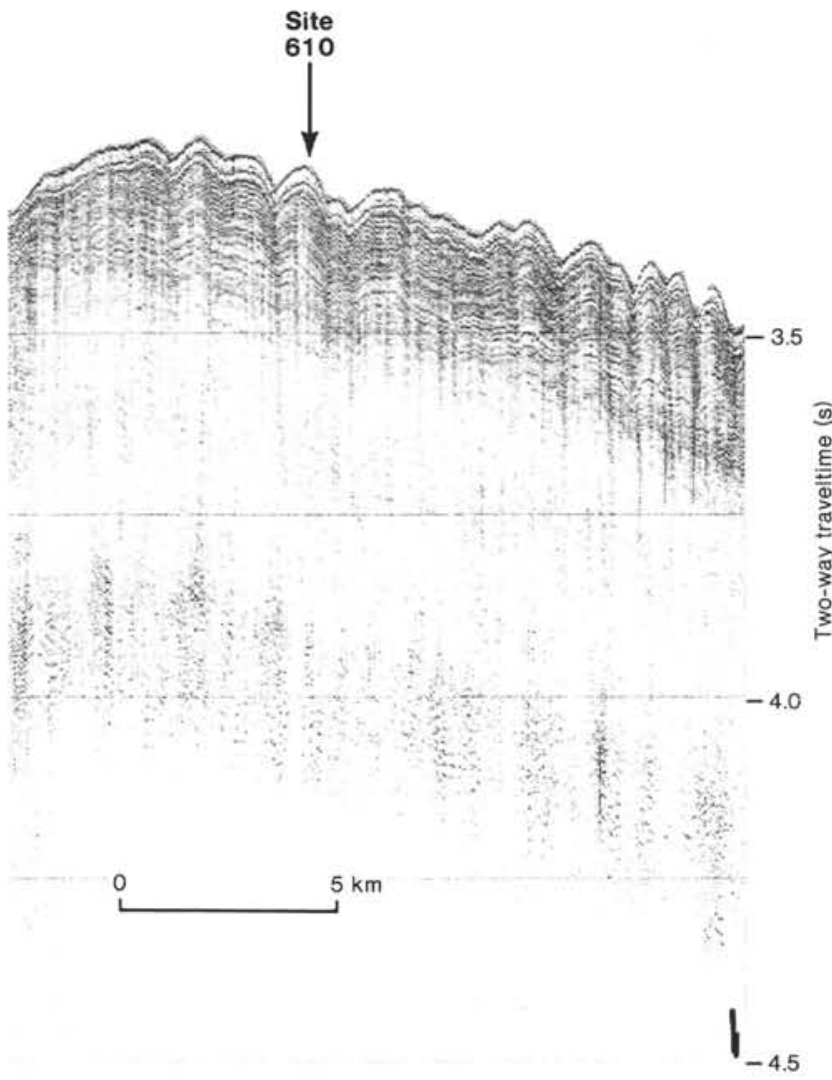

Figure 10. Water-gun profile from DSDP Leg 94, across Site 610, showing details of the internal structures of the sediment waves.
Roberts, D. G., Masson, D. G., and Miles, P. R., 1981. Age and structure of the southern Rockall Trough: New evidence. Earth Planet. Sci. Lett., 52:115-128.

Scrutton, R. A., and Roberts, D. G., 1971. Structure of the Rockall Plateau and Trough, north-east Atlantic. In Delany, F. M. (Ed.), The Geology of the East Atlantic Continental Margin. Rep. Inst. Geol. Sci., 70/14:77-87.

Searle, R. C., 1981. The active part of the Charlie-Gibbs Fracture Zone: A study using sonar and other geophysical techniques. $J$. Geophys. Res., 86:243-262.

Searle, R. C., and Laughton, A. S., 1977. Sonar studies of the MidAtlantic Ridge and Kurchatov Fracture Zone. J. Geophys. Res., $82: 5313-5328$.

Searle, R. C., and Whitmarsh, R. B., 1978. The structure of King's Trough, northeast Atlantic, from bathymetric, seismic, and gravity studies. Geophys. J. R. Astron. Soc., 53:259-287.

Somers, M. L., Carson, R. M., Revie, J. A., Edge, R. H., Barrow, B. J., and Andrews, A. G., 1978. GLORIA II-an improved longrange sidescan sonar. Proc. IEE/IERE Subconf. Offshore Instr. Comm. (Oceanol. Internat., 1978): London (B.P.S. Publications Ltd.), pp. 16-24.

Vogt, P. R., and Avery, O. E., 1974. Detailed magnetic surveys in the Northeast Atlantic and Labrador Sea. J. Geophys. Res., 79(2): 363-389.

Whitmarsh, R. B., 1982. RRS Discovery Cruise 131: 12 August-23 September 1982. Geology and geophysics of the Charlie-Gibbs Fracture Zone, North Atlantic Ocean. Inst. Oceanogr. Sci. Cruise Rept., 137.

Whitmarsh, R. B., Ginzburg, A., and Searle, R. C., 1982. The structure and origin of the Azores-Biscay Rise, north-east Atlantic Ocean. Geophys. J. R. Astron. Soc., 70:79-107.

Date of Initial Receipt: 5 November 1984

Date of Acceptance: 30 June 1985

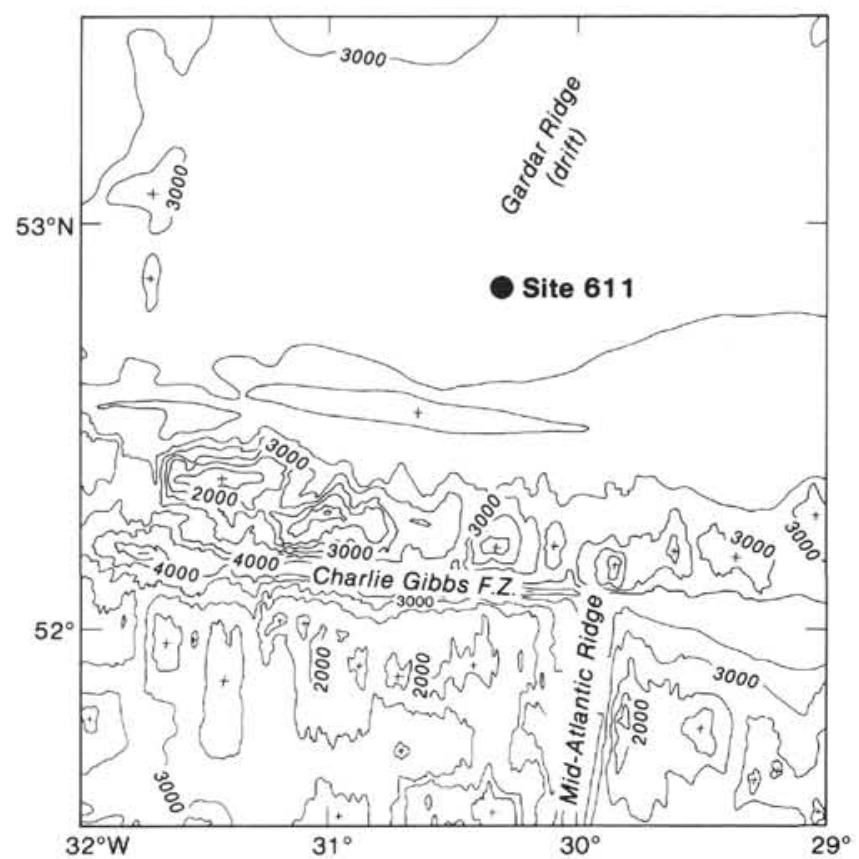

Figure 11. Bathymetry of the eastern end of Charlie Gibbs Fracture Zone and southern Gardar Ridge. From Laughton et al. (1982). Contour interval $500 \mathrm{~m}$. 


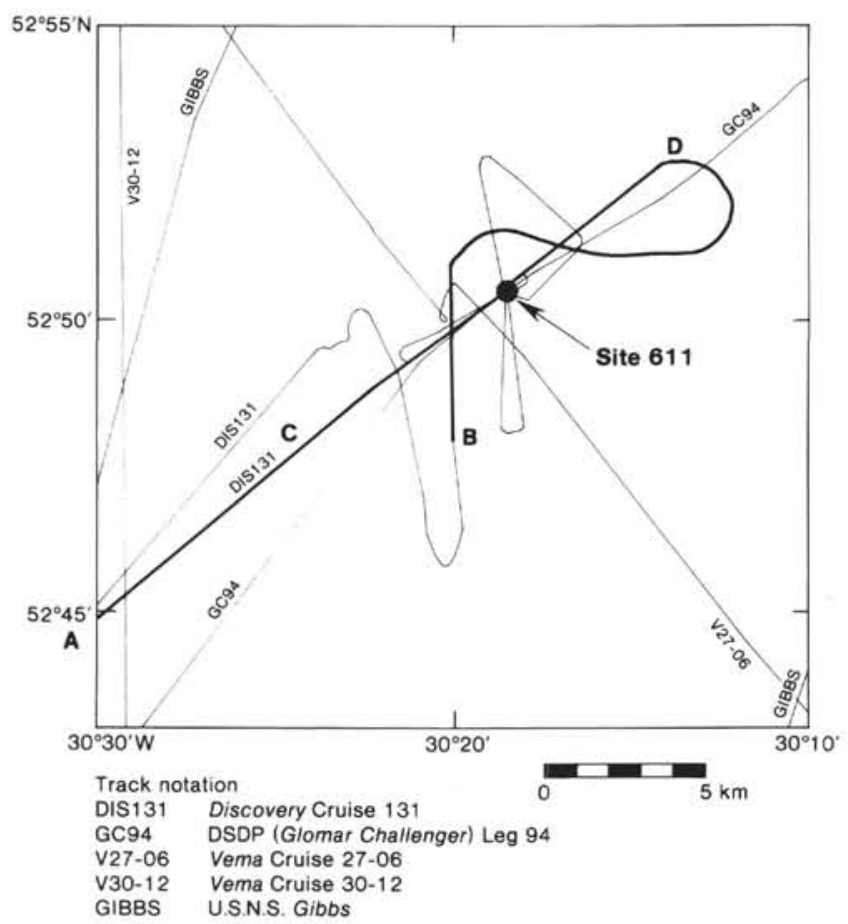

Figure 12. Site survey tracks for Site 611. A-B indicates location of seismic reflection profile in Figure 13. C-D indicates location of $3.5-\mathrm{kHz}$ profile in Figure 16.

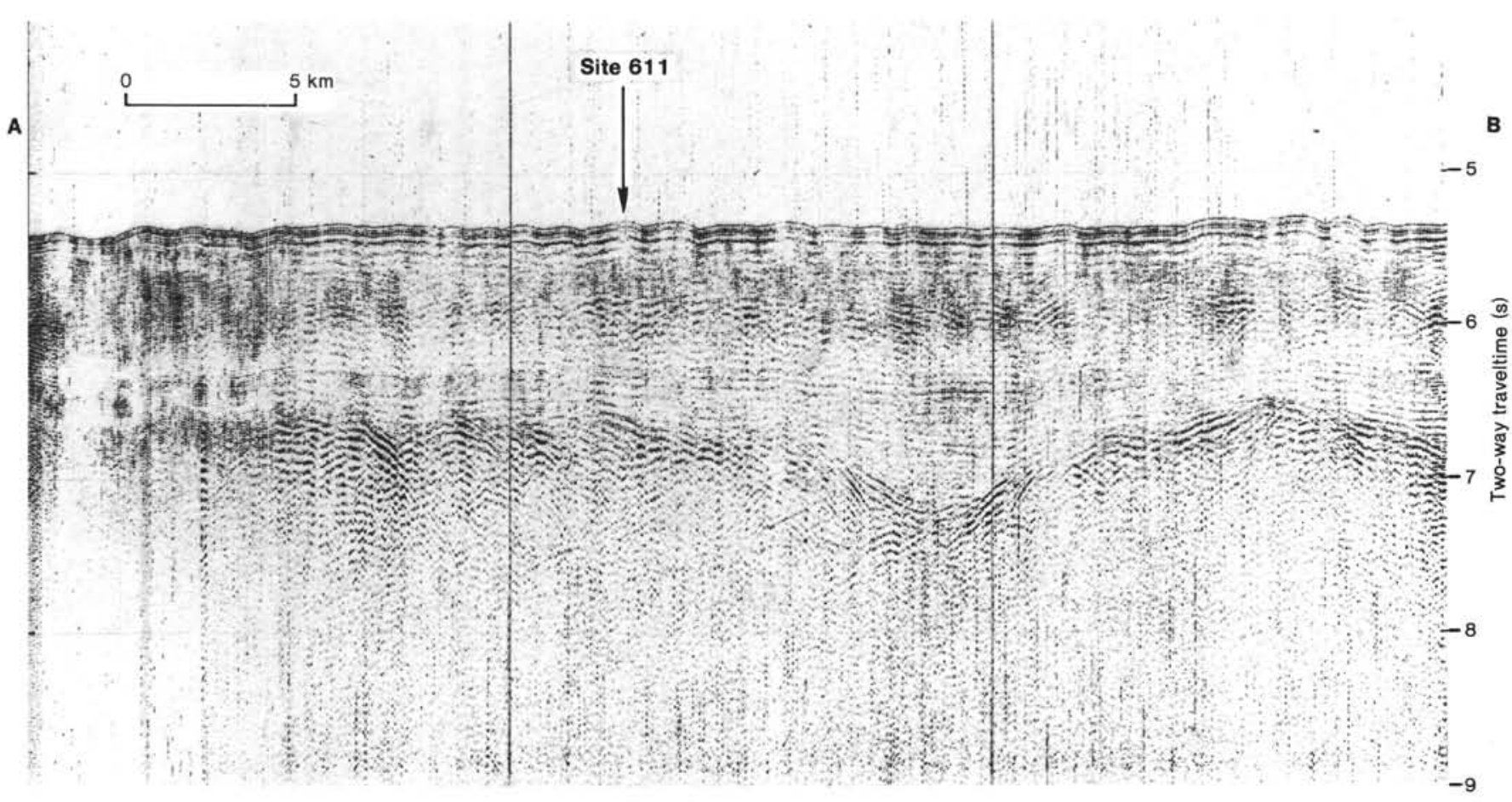

Figure 13. Single-channel seismic reflection profile obtained on Discovery Cruise 131, across Site 611. Location of section shown by line A-B on Figure 12 . 


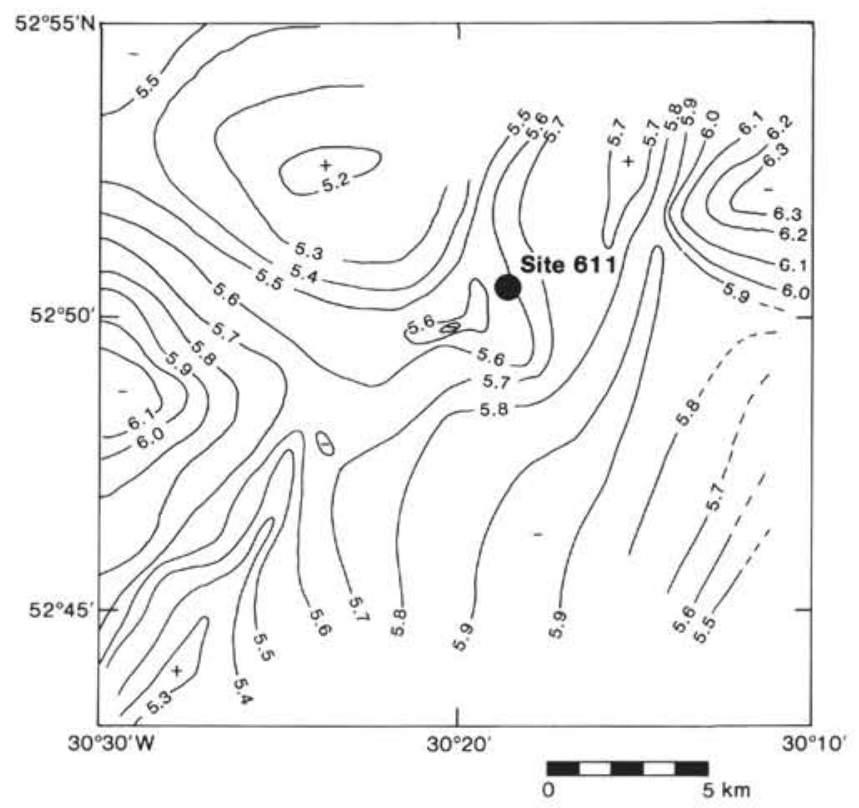

Figure 14. Total depth to basement in the area around Site 611, in seconds two-way traveltime. Contour interval $0.1 \mathrm{~s}$.

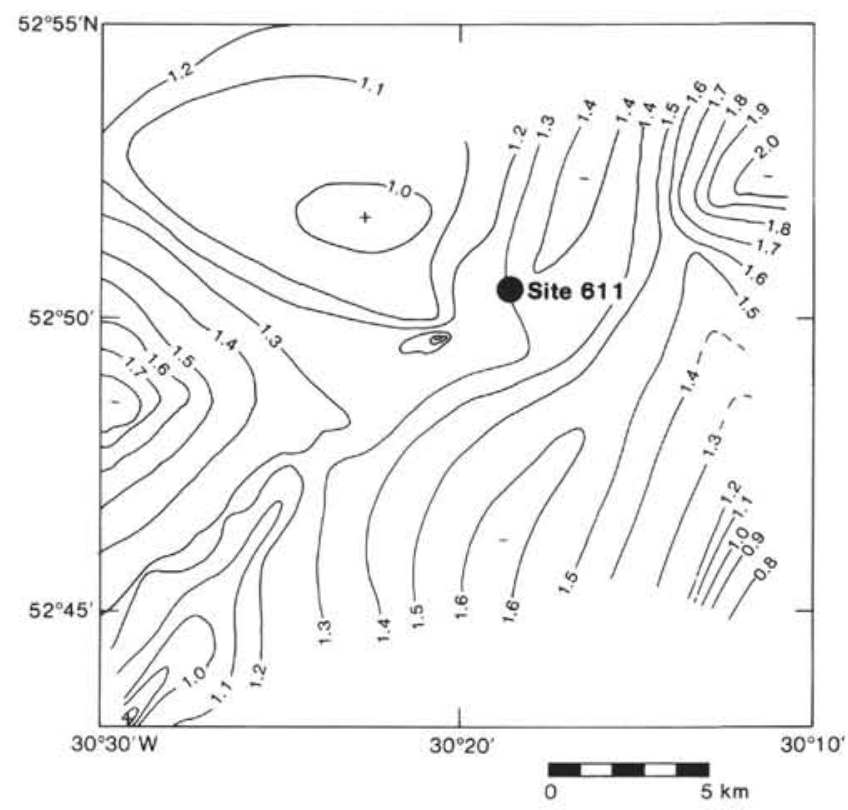

Figure 15. Sediment thickness in the area around Site 611 , in seconds two-way traveltime. Contour interval $0.1 \mathrm{~s}$. Location of section shown by line C-D on Figure 12. 


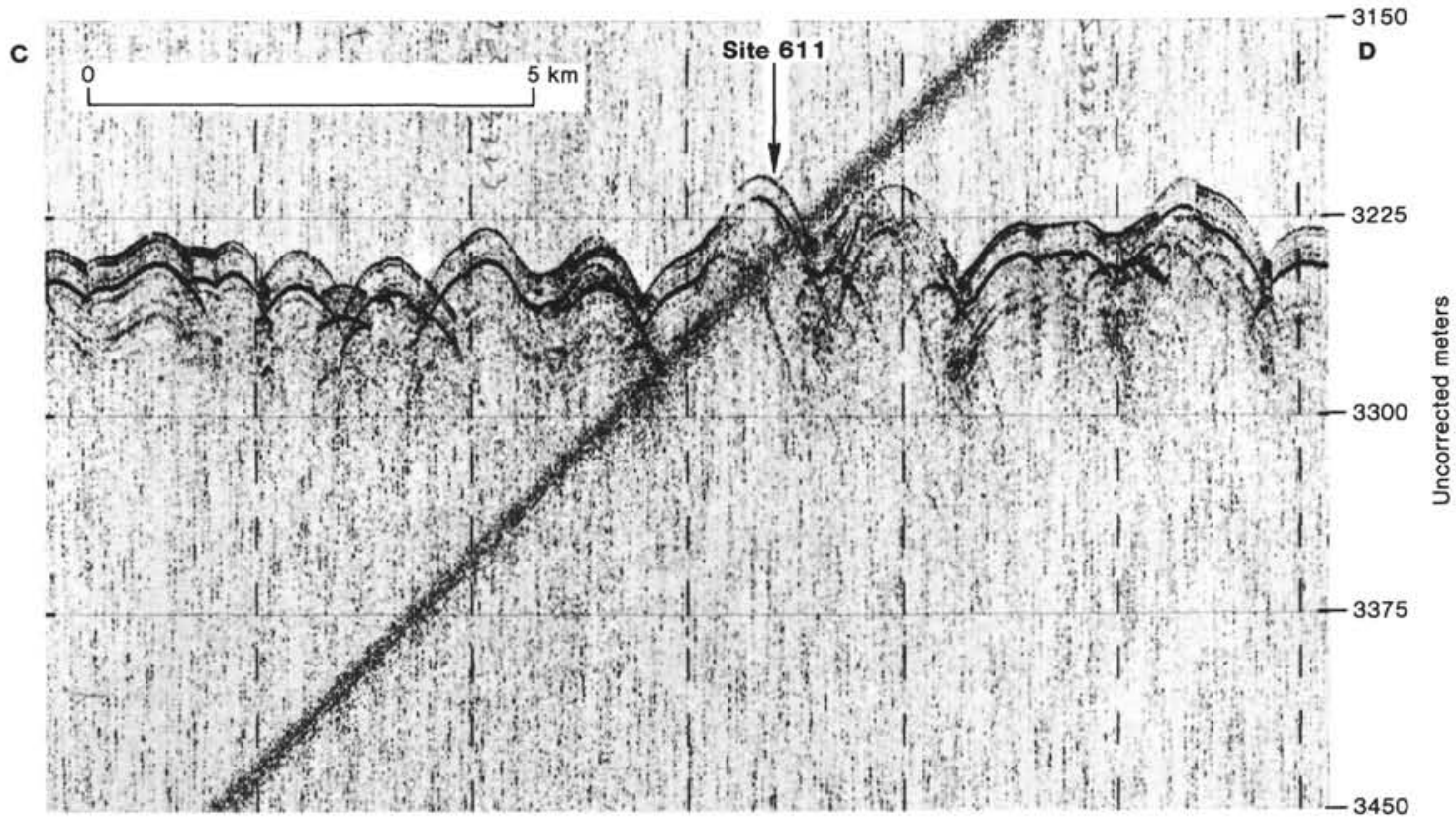

Figure 16. 3.5-kHz profile obtained on Discovery Cruise 131, showing the topography and near-surface acoustic stratigraphy of the sediment waves near Site 611 .

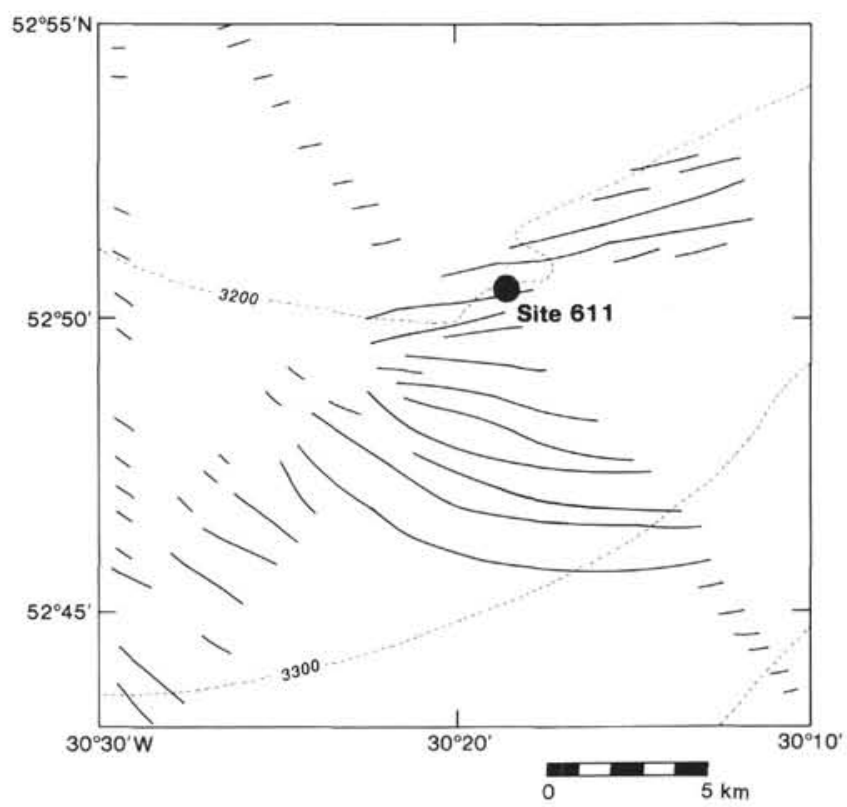

Figure 17. Trends of the crests of sediment waves around Site 611. Data from $3.5-, 10-$, and $12-\mathrm{kHz}$ records. Dashed line is bathymetry in corrected meters; contour interval $100 \mathrm{~m}$. 